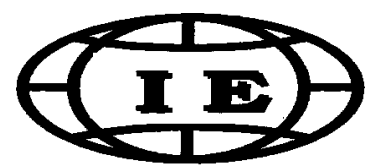

СТАТИСТИКА, ОБЛІК, АНАЛІЗ ТА АУДИТ

УДК 657.3:658.15:330.43

JEL Classification: C54, G32, M41

DOI: 10.37332/2309-1533.2019.5-6.20

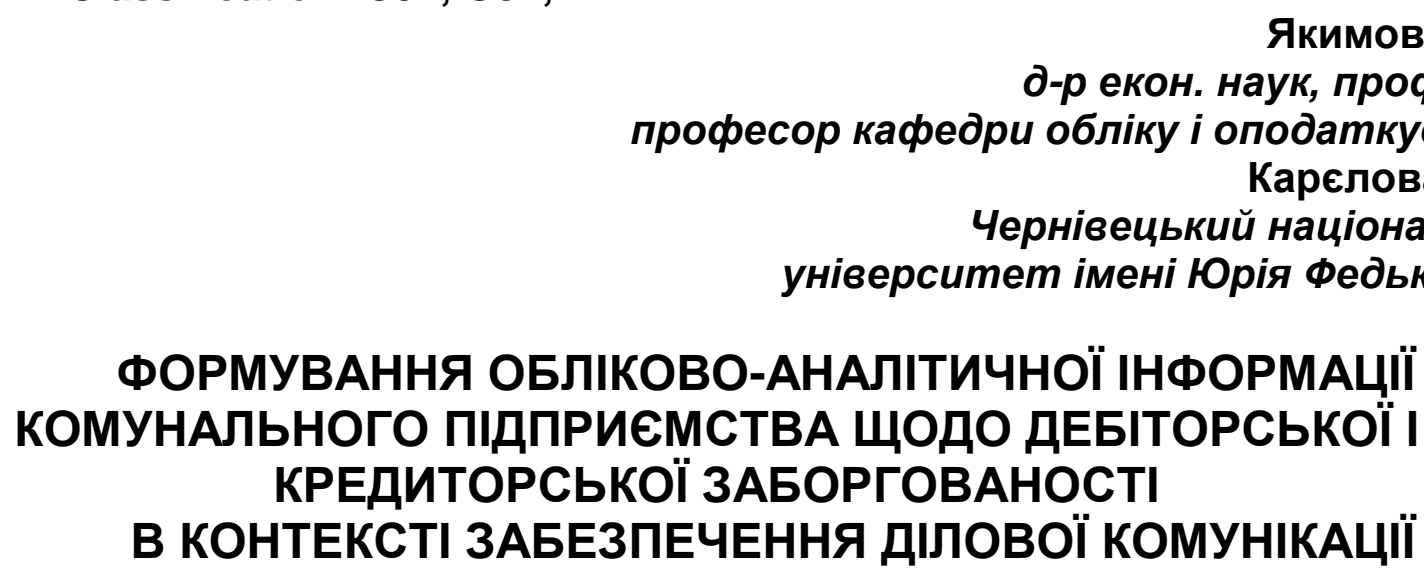

\begin{abstract}
Yakymova L.P., dr.sc.(econ.), professor, professor at the department of accounting and taxation, Karielova O.V., Yuriy Fedkovych Chernivtsi National University
\end{abstract}

\title{
FORMATION OF ACCOUNTING AND ANALYTICAL INFORMATION OF THE MUNICIPAL COMPANY ON ACCOUNTS RECEIVABLE AND PAYABLE IN THE CONTEXT OF ENSURING BUSINESS COMMUNICATION
}

Постановка проблеми. Сектор муніципальних послуг й інфраструктури в Україні протягом десятиліть потерпає від погіршення технічного обслуговування та нестачі інвестицій. Для підтримки міського господарства прибуткові комунальні підприємства (КП) на умовах поворотної фінансової допомоги змушені (за рішеннями міських рад) фрінансувати збиткові. Разом з тим, існують міжнародні програми допомоги комунальним підприємствам, зокрема «Проект розвитку міської інфраструктури 2» (Second Urban Infrastructure Project) Міжнародного банку реконструкції та розвитку. Міські КП змагаються за участь у таких проектах, що апріорі передбачає необхідність поліпшення комунікації у фрінансовій звітності підприємств, зокрема в аспекті розкриття інформації таким чином, щоб підвищити порівнянність між підприємствами. Зрозуміла і змістовна інформація необхідна й керівництву, контрагентам, банкам, які зазвичай зацікавлені в грошових потоках, і можуть затребувати спеціальну звітність щодо фінансової стійкості й ліквідності підприємства, включаючи дебіторську і кредиторську заборгованості.

Аналіз останніх досліджень i публікацій. Важливість ефрективності комунікацій в бухгалтерському обліку висвітлюється насамперед у закордонних теоретичних та емпіричних дослідженнях. Досвід компаній з різних галузей і частин світу, проаналізований у дослідженні Ради 3 міжнародних стандартів фрінансової звітності (International Accounting Standards Board) [1], показує, що відносно невеликі зміни можуть значно підвищити корисність фрінансової звітності. Компанії включали додаткову інформацію, яка корисна для інвесторів, або видаляли несуттєву, редагували примітки до фінансової звітності, представляли додаткові таблиці та графіки. Описані у дослідженні зміни пов'язані з принципами ефективної комунікації: адаптація інформації до специфіки компанії (entityspecific); використання простих описів і структур пропозицій без втрати корисної інформації (simple and direct); ранжування фрагментів інформації, щоб допомогти користувачам фрінансових звітів зрозуміти їхню важливість (better organised); зв'язування інформації, щоб допомогти користувачам фрінансових звітів зрозуміти взаємозв'язки між частинами інформації (better linked); вибір відповідного фрормату 
для типу інформації, яку надають компанії (better formatted); уникнення непотрібного дублювання, яке ускладнюе комунікацію (free of duplication); розкриття інфрормації таким чином, щоб підвищити порівнянність між компаніями та за звітні періоди без шкоди для її корисності (enhanced comparability). Льюїс Дж. (Lewis J.) підкреслює, «оскільки більша частина комунікації, яка відбувається у світі бухгалтерського обліку, відбувається завдяки використанню у письмових звітів, бухгалтери мають взяти на себе роль технічного письменника» [2]. Ефективна комунікація, комунікативні навички мають вирішальне значення для інтелектуальної взаємодії між бухгалтерами і одержувачами інформації [3; 4] та затребувані партнерами і менеджерами [5]. Базовою вітчизняною працею у цьому сенсі $\epsilon$ монографрія Пушкаря М. [6] щодо формування креативного обліку, призначенням якого $є$ розширення інформаційних ресурсів про нетрадиційні об'єкти (наукові розробки, охорону природи, логістику, маркетингові дослідження, інновації тощо), тобто генерування інформації на запит певних стейкхолдерів. Муравський В. [7] визначає складові облікової політики, їхній вплив на комунікаційні процеси підприємства та комунікаційні бар'єри в організації обліку і контролю. Кручак Л. і Муравський В. [8] обґрунтували можливості формування єдиної бази даних про контрагентів підприємства для дослідження комунікаційних і організаційних аспектів обліку дебіторської заборгованості. Задорожний 3.-М. та ін. [9] пропонують формувати інноваційний інформаційний простір для встановлення ефективних комунікацій між усіма сторонами договірних відносин як основу автоматизації управлінського обліку дебіторської та кредиторської заборгованості. Разом з тим, віддаючи належне напрацюванням вищеназваних науковців, загальним недоліком вітчизняних праць $€$ недостатність кількісних обґрунтувань та емпіричних досліджень, а також абстрактна узагальненість, водночас практична спрямованість обліково-аналітичного забезпечення передбачає врахування галузевих особливостей підприємств, їхньої форми власності тощо.

Постановка завдання. Метою дослідження $€$ обґрунтування методичних підходів до формування обліково-аналітичної інформації щодо дебіторської і кредиторської заборгованості в контексті забезпечення ділової комунікації комунального підприємства.

Виклад основного матеріалу дослідження. Аналіз теорії і практики управління розрахунками 3 контрагентами дозволив виділити основні проблеми щодо дебіторської та кредиторської заборгованостей в обліково-аналітичному аспекті та встановити залежності розв'язання деяких з них від принципів ділових комунікацій, яких слід дотримуватися партнерам під час встановлення ділових контактів (рис. 1). Перший принцип ділових комунікацій щодо поінформованості про фінансовий стан, імідж, кредитну історію контрагентів передбачає реалізацію принципу ефективної комунікації у фрінансовій звітності «підвищена порівнянність», тобто розкриття інформації таким чином, щоб підвищити порівнянність між компаніями та за звітні періоди без шкоди для її корисності [1]. Реалізація цього принципу передбачає фрормування обліково-аналітичної інформації з використанням відносних показників та формуванням відповідних зведених таблиць шляхом введення змін у «Примітки до річної фрінансової звітності» (форма 5) або формування нових документів, у тому числі для суб'єктів малого підприємництва, якими нерідко є КП.

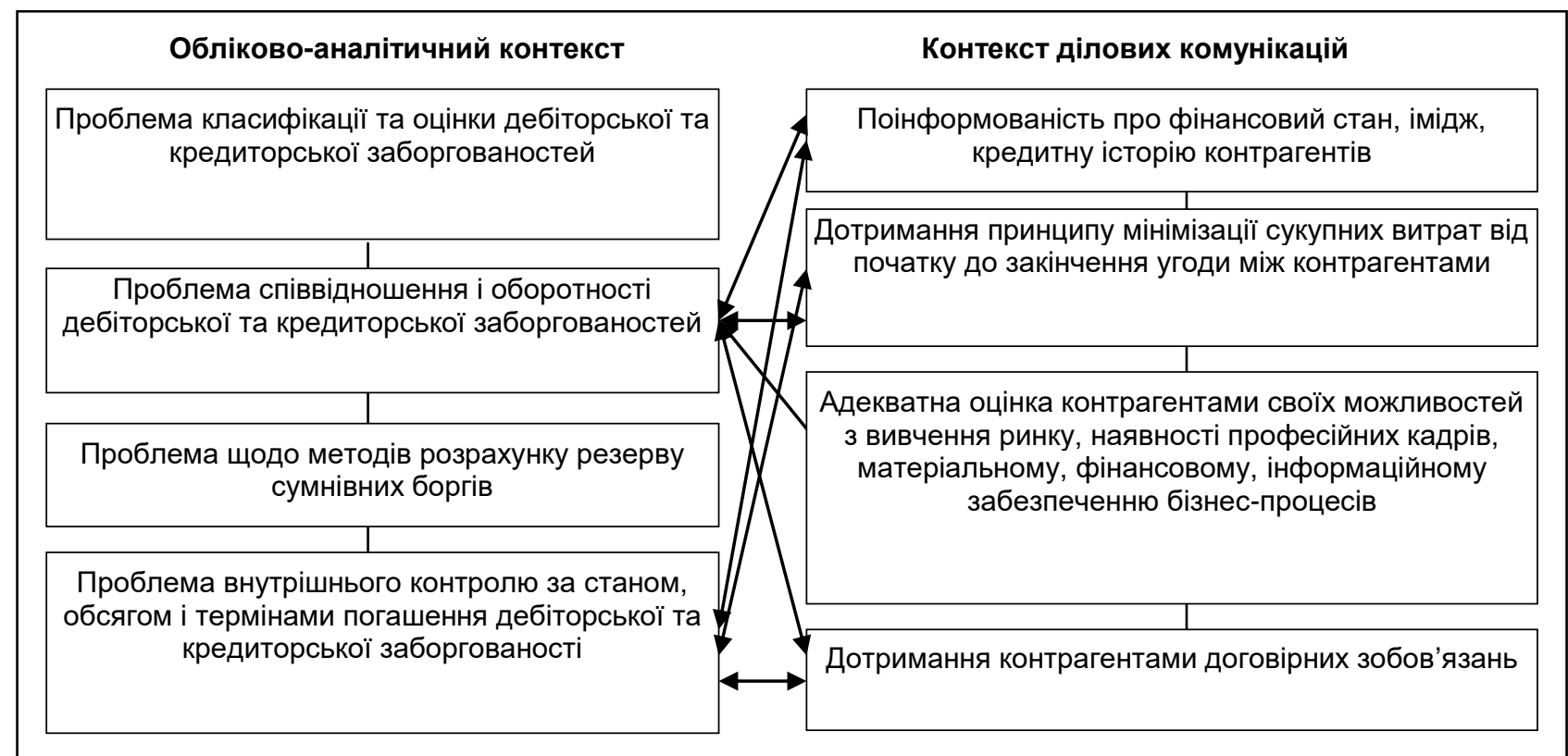

Рис. 1. Взаємозв'язок проблем обліку дебіторської та кредиторської заборгованостей і принципів ділових комунікацій

Джерело: складено авторами на основі [10] 
Отже, щоб поліпшити спосіб комунікації інформації у фрінансовій звітності, визначено ключові теми, найбільш важливі й актуальні для зацікавлених сторін, які формуються для дебіторської i кредиторської заборгованостей у таблицях такого вмісту: динаміка структури заборгованості за об'єктами виникнення, за термінами погашення, за своєчасністю погашення, за строками непогашення; за забезпеченістю, за безпечністю для фрінансового стану; динаміка показників стану й оборотності заборгованості (період погашення, коефіцієнт оборотності, коефріцієнт завантаження заборгованістю, частка а активах (пасивах)); порівняльний коефіцієнтний аналіз дебіторської та кредиторської заборгованості з наведенням оптимальних (рекомендованих) значень відповідних показників. Водночас згідно принципу «entity-specific» інформація має враховувати специфіку підприємства. Дослідження фокусується на комунальних підприємствах, основним видом діяльності яких $€$ надання в оренду й експлуатацію власного чи орендованого нерухомого майна. Для підприємств посередницьких, оптової та роздрібної торгівлі та інших підприємств нормативним (рекомендованим) $€$ період погашення дебіторської і кредиторської заборгованості до 30 днів, коефіцієнт оборотності - 12.

Згідно принципу «simple and direct» кожна таблиця має містити прості й зрозумілі, але без втрати корисної інфрормації, описи суджень, оцінок, рекомендацій керівництву. Наприклад, щодо меж оптимальності співвідношення дебіторської і кредиторської заборгованостей $\left(k_{R / P}\right)$ та відповідних управлінських заходів опис може бути наступним: «1) оптимальне значення $k_{R / P}$ варіюється в межах 0,9-1,0 (кредиторська заборгованість не повинна перевищувати дебіторську більше ніж на 10\%); рекомендовані оперативні управлінські заходи: контроль поточної політики управління розрахунками; 2) якщо $k_{R / P}<0,9$, існує загроза фінансовому стану підприємства за рахунок ймовірності неможливості погашення своїх зобов'язань через відсутність коштів; рекомендовані оперативні управлінські заходи: переглянути джерела фрінансування на користь власних коштів; 3 ) якщо $k_{R / P}>1$, існує ризик порушення фрінансової стійкості через відтік коштів з обороту, що призведе до необхідності залучення кредитів і позик для підтримки виробничо-господарської діяльності підприємства; рекомендовані оперативні управлінські заходи: переглянути вибір контрагентів на користь платоспроможних» [11].

Сукупність таких таблиць і супровідних описів дає інфрормацію про дебіторську та кредиторську заборгованості, але не містить зрозумілої користувачам інформації щодо впливу заборгованостей на фрінансове здоров'я КП та його перспектив. Тому комунальним підприємствам пропонується: поперше, розраховувати зведений показник M-Score, який враховує специфіку КП та є інструментом порівняння; по-друге, оцінити ступінь впливу дебіторської та кредиторської заборгованостей на фінансовий результат КП, його ліквідність.

Дискримінантна модель $M$-Score, оцінена за даними 50 українських КП і вериффікована за даними 71 муніципальної компанії країн Центральної та Східної Європи, має вигляд [12]:

$$
\begin{aligned}
& M-\text { Score }=0,0505 x_{1}+6,0638 x_{2}+0,3870 x_{3}+0,2193 x_{4}-0,0004 x_{5}-4,4234 \\
& \text { де } x_{1} \text { - коефіцієнт поточної ліквідності; } \\
& x_{2} \text { - коефріцієнт автономії; } \\
& \quad x_{3} \text { - коефріцієнт фондовіддачі; } \\
& \quad x_{4} \text { - коефріцієнт валового прибутку; } \\
& \quad x_{5} \text { - період погашення дебіторської заборгованості. }
\end{aligned}
$$

Модель M-Score є корисною для підвищення комунікації фрінансової звітності, оскільки її можна використовувати як для передбачення фрінансового здоров'я КП, так і для порівняльного аналізу 3 іншими КП. Правила прогностичної ідентифрікації фрінансового стану за $M$-Score наступні: якщо $M$ Score $>0,789$, КП буде фінансово здоровим (безпечна зона); якщо M-Score $<-0,936$, КП буде фінансово нездоровим (зона лиха); якщо $-0,936<M$-Score $<0,789$, однозначний висновок про фінансове здоров'я КП зробити не можна (зона невизначеності). Проте завжди слід пам'ятати: (1) якщо M-Score від'ємний, ймовірність лиха більше $50 \%$; (2) сіра зона невизначеності насправді характеризує критичний стан комунального підприємства.

Отримані результати прогностичної оцінки фрінансового стану комунальних підприємств (табл. 1) свідчать про те, що значення показника M-Score для всіх досліджуваних підприємств є додатним, що означає можливе фінансове здоров'я для цих компаній. Проте 2 з 11 підприємств фрактично знаходяться в зоні невизначеності (значення $M$-Score лежить у межах $(-0,936 ; 0,789)$ або на межі), що характеризує можливий критичний стан підприємства. Незважаючи на те, що більшість підприємств знаходяться в безпечній зоні, підприємствам необхідну підтримувати та прагнути до покращення фінансового здоров'я, щоб не потрапити до критичної зони. Потрібно зазначити, що це очікуваний результат, оскільки КП, що досліджуються за класифрікацією [12] є підприємствами «для отримання прибутку», на відміну від, так званих, життєво-необхідних енергетичних та водопостачальних КП. 
Результати прогностичної оцінки фінансового стану комунальних підприємств

Таблиця 1

\begin{tabular}{|l|c|c|c|c|c|c|c|}
\hline \multicolumn{1}{|c|}{ Комунальне підприємство } & $\begin{array}{c}\text { М- } \\
\text { Score }\end{array}$ & $x_{1}$ & $x_{2}$ & $x_{3}$ & $x_{4}$ & $x_{5}$ & Прогноз \\
\hline КП «Житній ринок», Київ & 0,626 & 0,839 & 0,813 & 0,166 & 0,218 & 77,005 & $\begin{array}{c}\text { зона } \\
\text { невизначеності }\end{array}$ \\
\hline $\begin{array}{l}\text { МКП-ринок «Ранковий», } \\
\text { Хмельницький }\end{array}$ & 0,798 & 0,845 & 0,809 & 0,432 & 0,505 & 15,705 & безпечна зона \\
\hline $\begin{array}{l}\text { КП «Паркування та ринок», } \\
\text { Чернігів }\end{array}$ & 1,534 & 1,806 & 0,938 & 0,157 & 0,605 & 32,362 & безпечна зона \\
\hline $\begin{array}{l}\text { КП «Бессарабський ринок», } \\
\text { Київ }\end{array}$ & 1,661 & 1,538 & 0,988 & 0,015 & 0,164 & 63,885 & безпечна зона \\
\hline $\begin{array}{l}\text { КП «Володимирський } \\
\text { Ринок», Київ }\end{array}$ & 1,838 & 3,509 & 0,989 & 0,040 & 0,369 & 16,166 & безпечна зона \\
\hline $\begin{array}{l}\text { КП «Запоріжринок», } \\
\text { Запоріжжя }\end{array}$ & 1,908 & 1,915 & 0,996 & 0,434 & 0,162 & 18,291 & безпечна зона \\
\hline $\begin{array}{l}\text { КП «Ринково-побутові } \\
\text { послуги», Кропивницький }\end{array}$ & 1,991 & 3,057 & 0,996 & 0,053 & 1,000 & 40,290 & безпечна зона \\
\hline $\begin{array}{l}\text { КП «МТК «Калинівський } \\
\text { ринок», Чернівці }\end{array}$ & 2,147 & 7,729 & 0,972 & 0,670 & 0,234 & 64,177 & безпечна зона \\
\hline КП «Ринок», Дубно & 2,178 & 7,689 & 0,943 & 1,168 & 0,201 & 7,937 & безпечна зона \\
\hline $\begin{array}{l}\text { КП «Малиновський ринок», } \\
\text { Одеса }\end{array}$ & 2,609 & 6,720 & 0,925 & 2,657 & 0,284 & 12,028 & безпечна зона \\
\hline $\begin{array}{l}\text { КП «Золочівський ринок», } \\
\text { Золочів }\end{array}$ & 2,636 & 3,216 & 0,807 & 4,999 & 0,325 & 7,381 & безпечна зона \\
\hline
\end{tabular}

Джерело: авторські розрахунки на основі даних з офіційних сайтів підприємств і міських рад

Що стосується висвітлення у фрінансовій звітності ступеню впливу заборгованостей на прибутковість КП, то пропонується використовувати економетричну модель, результативним показником якої є чистий прибуток, а чинниками - коефіцієнти співвідношення дебіторської і кредиторської заборгованості та їхньої оборотності. За результатами оцінки такої моделі визначаються показники граничної ефективності чинників (= оцінені коефіцієнти регресії) та більш інформативні для стейкхолдерів коефіцієнти еластичності (табл. 2).

Таблиця 2

Оцінка впливу співвідношення і оборотності дебіторської і кредиторської заборгованостей на прибутковість комунальних підприємств

\begin{tabular}{|l|c|c|c|c|}
\hline \multicolumn{1}{|c|}{ Комунальне підприємство } & $\begin{array}{c}\text { Коефіцієнт } \\
\text { Чистий } \\
\text { прибуток } \\
\text { співвідношення } \\
\text { дебіторської та } \\
\text { кредиторської } \\
\text { заборгованості }\end{array}$ & $\begin{array}{c}\text { Коефіцієнт } \\
\text { оборотності } \\
\text { дебіторської } \\
\text { заборгованості }\end{array}$ & $\begin{array}{c}\text { Коефріцієнт } \\
\text { оборотності } \\
\text { кредиторської } \\
\text { заборгованості }\end{array}$ \\
\hline $\begin{array}{l}\text { КП «МТК «Калинівський ринок», } \\
\text { Чернівці }\end{array}$ & 11296,0 & 5,447 & 5,687 & 15,318 \\
\hline КП «Володимирський Ринок», Київ & 6395,0 & 0,502 & 22,579 & 10,836 \\
\hline КП «Бессарабський ринок», Київ & 2363,0 & 4,447 & 5,713 & 24,672 \\
\hline КП «Малиновський ринок», Одеса & 1689,0 & 2,236 & 30,345 & 18,338 \\
\hline $\begin{array}{l}\text { МКП-ринок «Ранковий», } \\
\text { Хмельницький }\end{array}$ & 1563,0 & 0,682 & 23,242 & 6,315 \\
\hline КП «Запоріжринок», Запоріжжя & 801,0 & 0,918 & 19,956 & 12,970 \\
\hline КП «Паркування та ринок», Чернігів & 718,0 & 0,879 & 11,279 & 3,227 \\
\hline КП «Житній ринок», Київ & 220,0 & 0,670 & 4,740 & 2,271 \\
\hline КП «Золочівський ринок», Золочів & 90,5 & 1,117 & 49,451 & 29,038 \\
\hline КП «Ринок», Дубно & 81,6 & 0,588 & 45,985 & 48,052 \\
\hline $\begin{array}{l}\text { КП «Ринково-побутові } \\
\text { Кропивницький }\end{array}$ & 21,5 & 2,729 & 9,059 & 18,905 \\
\hline Оцінені коефріцієнти регресії & $-458,66$ & 1743,142 & 93,561 & $-138,401$ \\
\hline Частинні коесріцієнти еластичності & & 1,40 & 0,85 & $-1,04$ \\
\hline
\end{tabular}

Джерело: розрахунки на основі даних з офріційних сайтів підприємств і міських рад 
Частинні коефіцієнти еластичності показують на скільки відсотків збільшиться або зменшиться чистий прибуток, якщо один із чинників збільшиться на $1 \%$ при незмінних значеннях решти: найсуттєвіше впливає співвідношення дебіторської і кредиторської заборгованості; за коефіцієнтом оборотності дебіторської заборгованості чистий прибуток нееластичний; оборотності заборгованостей мають різнонаправлений вплив; негативний вплив оборотності кредиторської заборгованості на чистий прибуток відбиває його зниження, зокрема через те, що намагаючись швидко погасити заборгованість, КП втрачають можливості реінвестування коштів у розвиток.

Висновки з проведеного дослідження. Обліково-аналітична інфрормація має бути засобом комунікації, а не результатом простого дотримання вимог, вона має розглядатися як «живий документ», який підлягає постійному перегляду. Запропоновані у статті підходи до реструктуризації приміток до фінансової звітності комунальних підприємств узгоджуються з принципами ефективної комунікації, які визначені в «Board's Discussion Paper Disclosure Initiative-Principles of Disclosure» [1]. Але наведений перелік змін і пропозицій не є остаточним і може змінюватися у процесі діяльності комунальних підприємств та розвитку регіонів (територіальних громад). Вимагає додаткових досліджень й питання підвищення комунікації у фрінансовій звітності стосовно інших показників діяльності підприємств.

\section{Література}

1. Better Communication in Financial Reporting. Disclosure Initiative-Case Studies. IFRS Foundation, 2017. 46 p.

2. Lewis J. The Challenges in Communicating New Ideas in Accounting. Small Business Chron.com. 2019. URL: https://smallbusiness.chron.com/challenges-communicating-new-ideas-accounting18005.html (дата звернення: 23.07.2019).

3. Zaid O.A., Abraham A., Abraham A. Communication skills in accounting education: Perceptions of academics, employers and graduate accountants. Accounting Education. 1994. Issue 3. Volume 3. P. 205221. DOI: $10.1080 / 09639289400000020$.

4. Shanker S. Importance of Effective Communication in Accounting, Small Business - Chron.com. 2019. URL: http://smallbusiness.chron.com/importance-effective-communication-accounting-3169.html (дата звернення: 23.07.2019).

5. Stowers R. H., White G. T. Connecting Accounting and Communication: A Survey of Public Accounting Firms. Business Communication Quarterly. 1999. No.62(2). P. 23-40. DOI: https://doi.org/10.1177/108056999906200204.

6. Пушкар М. С. Креативний облік (створення інформації для менеджерів): монографрія. Тернопіль: Карт-бланш, 2006. 334 с.

7. Муравський В. В. Комунікаційні бар'єри в організації обліку і контролю. Науковий вісник Ужгородського університету. Серія «Економіка». 2015. Вип. 1(45). Т. 2. С. $402-405$.

8. Кручак Л., Муравський В. Автоматизація обліку дебіторської заборгованості на основі інтегрованої бази даних контрагентів. Вісник Тернопільського національного економічного університету. 2017. Вип. 1. С. 109-118.

9. Zadorozhny Z., Muravskyi V.V., Shevchuk O.A., Sudyn Y.A. Management accounting of the settlements with contractors in innovative environment of business communications. Marketing and Management of Innovations. 2018. № 2. P. 103-112.

10. Матузенко Е.В., Шиленко С.И., Федорова Я.О. Деловые коммуникации как фактор повышения результативности бизнеса. Фундаментальные исследования. 2016. № 9 (ч. 3). С. 622-627.

11.Якимова Л. П., Мацкуляк К. І. Аналітичне забезпечення управління розрахунками 3 контрагентами в контексті забезпечення платоспроможності підприємства. Проблеми економіки. 2018. № 2(36). C. 396-402.

12. Yakymova L., Kuz, V. The use of discriminant analysis in the assessment of the municipal company's financial health. Economics and Sociology. 2019. № 12(2). P. 64-78. DOI: 10.14254/2071789X.2019/12-2/4.

\section{References}

1. IFRS Foundation (2017), Better Communication in Financial Reporting. Disclosure Initiative-Case Studies, IFRS Foundation, $46 \mathrm{p}$.

2. Lewis, J. (2019), "The Challenges in Communicating New Ideas in Accounting", Small Business Chron.com, available at: http://smallbusiness.chron.com/challenges-communicating-new-ideas-accounting18005.html (access date July 23, 2019).

3. Zaid, O.A., Abraham, A. and Abraham, A. (1994), "Communication skills in accounting education: Perceptions of academics, employers and graduate accountants", Accounting Education, Issue 3, Volume 3. pp. 205-221, DOI: 10.1080/09639289400000020.

4. Shanker, S. (2019), "Importance of Effective Communication in Accounting", Small Business Chron.com, available at: http://smallbusiness.chron.com/importance-effective-communication-accounting3169.html (access date July 23, 2019). 
5. Stowers, R.H. and White, G.T. (1999), "Connecting Accounting and Communication: A Survey of Public Accounting Firms", Business Communication Quarterly, no. 62(2), pp. $23-40$. DOI: https://doi.org/10.1177/108056999906200204.

6. Pushkar, M.S. (2006), Kreatyvnyi oblik (stvorennia informatsii dlia menedzheriv) [Creative Accounting (Creating Information for Managers)], monograph, Kart-blansh, Ternopil, Ukraine, 334 p.

7. Muravskyi, V.V. (2015), "Communication barriers in accounting and control organization", Naukovyi visnyk Uzhhorodskoho universytetu. Seriia "Ekonomika”, Iss. 1(45), Vol. 2, pp. 402-405.

8. Kruchak, L. and Muravskyi, V. (2017), "Automation of receivables accounting based on the integrated database of counterparties", Visnyk Ternopilskoho natsionalnoho ekonomichnoho universytetu, Iss. 1, pp. 109-118.

9. Zadorozhny, Z., Muravskyi, V.V., Shevchuk, O.A. and Sudyn, Y.A. (2018), "Management accounting of the settlements with contractors in innovative environment of business communications", Marketing and Management of Innovations, no. 2, pp. 103-112.

10.Matuzenko, E.V., Shilenko, S.I. and Fedorova, Ya.O. (2016), "Business communications as business fecundity improvement factor", Fundamentalnyye issledovaniya, no. 9 (part 3), pp. 622-627.

11.Yakymova, L.P. and Matskuliak, K.I. (2018), "Analytical support for managing settlements with counterparties in the context of ensuring enterprise solvency", Problemy ekonomiky, no. 2(36), pp. 396-402.

12. Yakymova, L. and Kuz, V. (2019), "The use of discriminant analysis in the assessment of the municipal company's financial health", Economics and Sociology, no. 12(2), pp. 64-78. DOI:10.14254/2071789X.2019/12-2/4.

Стаття надійшла до редакції 05.08.2019 p.

УДК 657.421.3.011.1

DOI: 10.37332/2309-1533.2019.5-6.21

JEL Classification: M 40

Ясишена В.В., канд. екон. наук, доцент, доцент кафедри економіки, обліку та оподаткування, Вінницький навчально-науковий економічний інститут Тернопільського національного економічного університету

\title{
ОСНОВНІ АСПЕКТИ ФОРМУВАННЯ ОБЛІКОВОЇ ПОЛІТИКИ НЕМАТЕРІАЛЬНИХ АКТИВІВ ПІДПРИЕМСТВ
}

\author{
Yasyshena V.V., \\ cand.sc.(econ.), assoc. prof., associate professor \\ at the department of economics, accounting and taxation, \\ Vinnytsia Education and Research Institute of Economy \\ of Ternopil National Economic University
}

\section{THE MAIN ASPECTS OF ACCOUNTING POLICIES OF INTANGIBLE ASSETS OF ENTERPRISES}

Постановка проблеми. Останніми роками як в Україні, так і за кордоном стрімко зростає роль нематеріальних активів (HМA) в діяльності суб'єктів господарювання, що потребує удосконалення методологічних і практичних підходів до формування їх облікової політики. Обрана облікова політика має вплив на конкурентоспроможність підприємства, оперативність проведення господарських операцій, своєчасність передачі інформації, ефективність прийнятих управлінських рішень, у т.ч. і в частині HМА. Тому на сьогодні виникає нагальна потреба у розробці та впровадженні на вітчизняних підприємствах ефективної та раціональної облікової політики, яка була б направлена на вибір дієвих методичних прийомів способів і процедур обліку, оподаткування, контролю НМА.

Аналіз останніх досліджень і публікацій. Теоретичні та методологічні засади формування облікової політики досліджували в своїх працях провідні вітчизняні і зарубіжні економісти, такі як 